\title{
A broader view of communicative competence for aeronautical communications: Implications for teaching and high-stakes testing
}

Uma visão mais ampla de competência comunicativa para comunicações aeronáuticas: Implicações para o ensino e exames de alta relevância

Ana Lúcia Tavares MONTEIRO (ANAC) ${ }^{1}$

Neil BULLOCK (Lancaster University) ${ }^{2}$

\section{ABSTRACT}

This paper examines language used in radio communication between pilots and Air Traffic Controller Officers (ATCOs). It demonstrates that such communication is extremely complex, requiring a certain level of technical knowledge and is influenced by many other observable factors. Using research data from two studies involving nearly 200 aviation English professionals, this paper first presents a matrix that maps the construct of aeronautical radiotelephony (RT) communication (MONTEIRO, 2019a). Then, it explores the perceptions of a group of pilots and ATCOs on the multiple factors that may impact communication in this professional context. There then follows an application of this emerging list of factors in the analysis of a non-routine scenario of pilot/ATCO interaction. Integration of findings confirms the many complex features that form the communicative exchanges in this highly technical domain and the range of competencies required for effective and safe outcomes. Implications for teaching and high-stakes testing of these aviation professionals are discussed with the aim of improving communicative competence above a purely linguistic level and to increase the validity of inferences drawn from test results.

Keywords: communication, pilot, ATCO, English, aviation

\section{RESUMO}

Este artigo examina a linguagem usada nas comunicações de rádio entre pilotos e controladores de tráfego aéreo (ATCO). Ele demonstra que essa comunicação é extremamente complexa, requerendo um certo grau de conhecimento técnico e é influenciada por muitos outros fatores observáveis. Usando dados de pesquisa de dois estudos envolvendo quase 200 profissionais da área do inglês aeronáutico, este artigo apresenta primeiro uma matriz que mapeia o construto da comunicação radiotelefônica aeronáutica (MONTEIRO, 2019a). Depois, ele explora as percepções de um grupo de pilotos e ATCOs sobre os múltiplos fatores que podem impactar a comunicação nesse contexto profissional. Segue-se a aplicação dessa lista emergente de fatores na análise de um cenário não-rotineiro de interação piloto/controlador. A integração dos resultados confirma as várias características complexas que constituem as trocas comunicativas nesse domínio altamente técnico e a variedade de competências requeridas para resultados eficazes e seguros. Implicações para o ensino e exames de alta relevância desses profissionais são discutidas com o objetivo de aprimorar a competência comunicativa acima de

\footnotetext{
${ }^{1}$ National Civil Aviation Agency, Rio de Janeiro, RJ, Brazil. Language Proficiency Assessment Coordination; ORCID: https://orcid.org/0000-0001-9187-1677; ana.monteiro.icaea@gmail.com

${ }^{2}$ Lancaster University, Lancaster, UK. Department of Linguists and English Language; ORCID: https://orcid.org/0000-00034419-3329; n.bullock@lancaster.ac.uk
} 
um nível puramente linguístico e de aumentar a validade das inferências extraídas a partir de resultados de testes.

Palavras-Chave: comunicação, piloto, controlador de tráfego aéreo, Inglês, aviação

\section{Introduction}

In the time that the International Civil Aviation Organization (ICAO) Language Proficiency Requirements (LPRs) have been in force, observers have noted that language for aviation communication has often been taught and tested as an isolated entity, with little correlation to the language and the contextual factors that are prevalent in real-world communication. This has been suggested as a reason for a certain disconnect between operational personnel and the LPR system coupled with an almost contemptuous reaction to many LPR tests. Teaching, and particularly testing, of aviation English language are not seen as relevant to the day-to-day communication of pilots and controllers (KIM, 2013, 2018; BULLOCK, 2019).

Kim (2013) gave an indication of the issue with research from Korean pilots who clearly saw that, in the system that was developed to test their language proficiency, the "test content was inappropriate and irrelevant to the demands" of their job (p. 105). Bullock (2019) argued for a change of perspectives in Language for Specific Purposes (LSP) teaching towards a methodology that would adopt a more "inclusive communication and knowledge-based approach" (p. 79). Kim (2018) again alluded to going beyond the purely linguistic approach when she noted that "professional knowledge plays a critical role in naturally occurring professional settings, and understanding language use and performance embedded in the contexts is complex" (p. 418).

Communication between pilots and ATCOs certainly includes language, although based on predefined communicative functions, rules and shared knowledge. During routine situations such communication requires the use of standard phraseology. During non-routine and unexpected situations, where phraseology does not cover the communicative requirements, pilots and controllers must use plain language (ICAO, 2010). The communicative functions of such plain language originate both from standardized technical vocabulary, which includes collocations, compounds and abbreviations, and general-purpose language (BULLOCK, 2015). This fusion of standard phraseology, technical and functional language with general-purpose language can therefore be described as a Language for Specific Purposes (LSP) (PALTRIDGE; STARFIELD, 2013).

In any specific purpose language communication, however, all inherent domain-specific knowledge shared between speakers carries very specific references which are critical in conveying meaning and understanding in the communicative tasks. Douglas (2000), in fact, sees language knowledge and technical knowledge as inseparable. In addition to this shared knowledge, we can also see that communication, and consequently, language, is affected by additional external factors. Bullock 
(2018), in trying to identify non-linguistic effective factors in aeronautical communication, categorized such influences as manageable and influential (p. 8). Manageable factors allow the communicators to exercise some degree of control over the influence of the factoral element - planning, anticipation, listening, adopting standard procedures, etc. Influential factors were seen as those that are inherent and whilst carrying large degrees of influence, may not be directly manageable. Such elements could be: equipment limitations, cultural influences, weather, environment, political, etc.

It follows therefore that if specific purpose language is to be assessed, it should also be accepted that functional language and knowledge be included when defining the construct, as well as all effective factors that mirror the real-world operational construct of the specific purpose communication. Only then can it really be said that the assessment instrument truly provides a valid result of the language that is required to be assessed. The main objective, therefore, of this paper is to demonstrate the many complex features that form the communicative exchanges in this highly technical domain, over and above language in isolation. It will suggest how these findings can be employed to better align teaching and high-stakes testing practices with current understanding of language use and with the requirements of the Target Language Use (TLU) domain.

\section{Literature review}

Research on the multiple factors that may impact communication in the occupational context of international aeronautical radiotelephony has been conducted extensively (e.g., CUSHING, 1994; EUROCONTROL, 2004, 2006; FLIGHT SAFETY FOUNDATION, 2000; GRAYSON; BILLINGS, 1981; MCMILLAN, 1998; MORRISON; WRIGHT, 1989; MORROW; RODVOLD, 1998; ORASANU; DAVISON; FISCHER, 1997; PRINZO; BRITTON, 1993; etc). Most of these factors were obtained from analyses of incident reports, recordings of pilot-controller interactions, discourse analysis of incidents and accidents transcriptions, or from experimental simulation-generated taxonomies and categorizations. Monteiro (2012) compiled and reorganized some of these lists to propose a taxonomy of factors related to radiotelephony communications failures, comprising: linguistic factors, discursiveinteractional factors, intercultural factors, other Human Factors, equipment and/or signal transmission. This taxonomy was later expanded to account for the perspectives of Brazilian pilots and ATCOs (see MONTEIRO, 2012, p. 60).

As a way of continuing to develop a clearer understanding of communication in aviation, research is continuously being carried out on factors that trigger miscommunications, both in different contexts and in different regions of the world (e.g., BULLOCK, 2018; ESTIVAL; FARRIS; MOLESWORTH, 2016; FRIGINAL; MATHEWS; ROBERTS, 2019; MATHEWS，2011; 2018; MOLESWORTH; ESTIVAL, 2015; MONTEIRO, 2018; PACHECO, 2018). It is worth highlighting a 
few of them due to their relevance or relation to the present study. To begin with, a taxonomy called LHUFT (Language and Culture as Human Factors), developed by Embry-Riddle Aeronautical University (MATHEWS, 2011), accounts for technical, procedural, language and cultural factors, designed to assist incident and accident investigators. Secondly, a more in-depth exploration of transcripts from authentic interactions between pilots and ATCOs was also conducted (MONTEIRO, 2018, 2019a), focusing on the impact of culture on effective radiotelephony communication, generating a taxonomy of intercultural factors in international pilot-ATCO communication. Thirdly, using Subject Matter Experts (SMEs) as participants, a pilot study (BULLOCK, 2018) was carried out with the objective of mining the perspectives of a group of experienced pilots and ATCOs, who were also trained language assessors, to try and respond to criticism that the ICAO LPRs were too language focussed and did not reflect the communication used in real-world operational communication. Its main purpose was to identify as many contextual factors inherent in radiotelephony communication as possible, over and above purely linguistic factors. Participants were primed to brainstorm their thoughts and ideas at the beginning of an Assessor refresher training module using Mentimeter ${ }^{3}$ software to collect participants' samples in response to the question: "What factors affect pilot/ATCO communication?". The responses were coded as manageable and influential because of the potential competency in the ability of speakers to manage and remedy a situation (manageable) or not (influential). They were then sub-coded into those likely to affect pilots and ATCOs alone (See Figure 1).

Data from the pilot study showed a clear awareness from SMEs of understanding the importance of how many additional factors can affect pilot/ATCO communications, over and above simple linguistic elements. These initial findings clearly show a potential for further studies to generate more valuable data which would allow for a better understanding of all the factors that impact pilot and ATCO interactions in radiotelephony. This understanding is crucial when it comes to the language assessment of this specific group of professionals. Defining what needs to be measured in language for specific communicative purpose tests must take into account not only the language, but the knowledge and the factors that affect the very same communication.

\footnotetext{
${ }^{3}$ Mentimeter is an interactive software used in presentations and classes that allows brainstorming of ideas and accumulation of data through downloading of Excel files, while at the same time preserving anonymity.

(https://www.mentimeter.com/features).
} 
Figure 1. Results of pilot study into "what factors affect pilot/ATCO communications"

\begin{tabular}{|c|c|}
\hline ATCO & Pilot \\
\hline Manageable & Manageable \\
\hline Anticipation / preparation / planning & Controlling, managing aircraft \\
\hline Listening (other frequencies /colleagues) & Flight preparation \\
\hline Phone calls & Language proficiency \\
\hline Planning - mental/external & Listening to more than one frequency / aircraft \\
\hline Reacting & Negotiating / informing / instructing \\
\hline \multirow[t]{3}{*}{ Scanning - screens, aerodrome, weather, etc } & Problem - SARPS/checklists/problem solving \\
\hline & Technical issues \\
\hline & Expectancy \\
\hline Influential & Influential \\
\hline Emergency situations $-3^{\text {rd }}$ parties & Cultural influences \\
\hline Equipment limitations and serviceability & $\begin{array}{l}\text { Multiple discourse communities: - passenger, } \\
\text { cabin crew, ATC, Operations, Handling agent. }\end{array}$ \\
\hline $\begin{array}{l}\text { External events (Volcanic Ash / Strikes / } \\
\text { Weather) }\end{array}$ & $\begin{array}{l}\text { Specifics of a situation (technical issues, } \\
\text { passengers, weather) }\end{array}$ \\
\hline Flight plan management & $\begin{array}{l}\text { Technical limitations of communications / } \\
\text { ground facilities }\end{array}$ \\
\hline Language proficiency of other speakers & TWR/GRD/ACC/APP - ATCO workplace \\
\hline Sub consciousness & \\
\hline
\end{tabular}

Source: Bullock (2018, p. 70)

Scholars in the field of language assessment, particularly in LSP contexts or professional contexts, have long discussed the importance of these factors. Douglas (2000, p. 7) explains that "if we wish to interpret a person's test performance as evidence of language ability in a specific language use situation, we must engage the test-taker in tasks which are authentically representative of that situation". In addition, test developers need to rely on the perspectives of domain experts in defining the assessment criteria with which to judge test-takers' performances, drawing "from an analysis of indigenous criteria in the TLU situation" (DOUGLAS, 2001, p. 181). The author argues that "just as we mine the TLU situation for LSP test content and methods, there is much to be gained from going to that same source for assessment criteria" (p. 183). Elder et al. (2017, p. 14) corroborate the need to consider the values of domain experts, arguing that in specific purpose language assessment, such as academic and occupational contexts, "neglect of the perspective of lay (i.e., non-linguistic) judges on language and communication is a serious validity concern, since they are the ultimate arbiters of what matters for effective communication in the relevant context of language use". The construct of professional communicative competence based on 'indigenous' assessment criteria has been articulated by scholars 
in different fields of enquiry (e.g., DOUGLAS; MYERS, 2000; ELDER; MCNAMARA, 2016; ELDER et al., 2017; FOX; ARTEMEVA, 2017; JACOBY; MCNAMARA, 1999; PILL, 2016; for a review see KNOCH; MACQUEEN, 2016), highlighting the importance of defining criteria that can be used to assess performance on a language test based on what domain experts consider as communicative effectiveness.

In relation to the specific purpose assessment of aeronautical English, Douglas (2004, p. 10) reinforces that "test developers need to learn more about the indigenous criteria experienced pilots and ATCOs use when evaluating the performance of their colleagues, so that these criteria can inform aviation English performance assessment". This has been done by some researchers, investigating the domain of aeronautical communication, who took an ESP perspective on construct definition (e.g., ARAGÃO, 2018; KIM, 2012, 2018; KIM; ELDER, 2015; KNOCH, 2014; MONTEIRO, 2019a, 2019b). In her investigation of the construct of aeronautical radiotelephony in the context of international aviation in Korea, Kim (2012, p. 229) argued that the 'indigenous' assessment criteria is essential to determine what really matters for communicative success, and that "linguistically oriented criteria alone cannot capture the key aspects of communication in this professional setting". Findings from her study suggest that "what matters most for radiotelephony communication is thorough observance of the prescribed conventions, professional knowledge as embedded in efficient transmissions, appropriate speech rate, and strategic skills to deal with aviation personnel with different levels of expertise". Likewise, in her investigation of aspects of professional competence that contribute to effective RT communication, Kim (2018) reports on the role of background knowledge, sensitivity to each other's roles and tasks, compliance with RT conventions, ability or willingness to accommodate, and shared responsibility for communication failure. She argues that "the co-constructed nature of interactional competence is not at all reflected in the traditional linguistic-based ICAO rating scale. Interaction in the setting of air traffic control demands not just good language skills but also sufficient professional knowledge" (p. 420).

Similar findings were reported by Monteiro (2019a), who, in the second phase of her study, investigated the ESP construct of international aviation RT communication in order to map the relevant components in a matrix of construct specification and further validate it with key aviation stakeholders. The author highlighted that "in order to communicate effectively in a lingua franca setting, pilots and ATCOs, both NSs and NNSs of English, need to develop skills and competencies that go beyond language proficiency" (p. 344). One of the outcomes of Monteiro's (2019a) study, the matrix of construct specification within the aviation RT domain, organized the components of the construct according to their best fit with the dimensions of awareness, knowledge, skills, and attitudes, and the 
domains of Aviation English (AE), English as lingua franca (ELF), Intercultural awareness/competence (ICA), and Interactional competence (IC). This matrix will be discussed later in this paper.

From the above discussion we can infer that a complex array of issues, such as non-compliance with existing standards coupled with language and cultural factors can lead to misunderstandings, thus compromising safety. In addition, a lack of awareness of current theories of language use brought by a globalized and multilingual world (i.e, using English as a lingua franca in intercultural communications), combined with a lack of understanding of communication as co-constructed and the role of both interlocutors to achieve successful outcomes (i.e., interactional competence), underscores the need for further investigations. Therefore, the present paper attempts to address those needs by proposing ways to align teaching, learning and assessment to the communicative requirements of the TLU domain of aeronautical communications. In the next section, the objectives and research questions that guide this paper are presented in more detail.

\section{Research Objectives}

Despite efforts to identify factors that may cause miscommunications during less than effective exchanges between pilots and ATCOs, and regardless of the studies already available on ways to improve the teaching of aviation professionals involved in RT communication (e.g., BOROWSKA, 2015; BULLOCK, 2015, 2018, 2019; ESTIVAL, 2018; MONTEIRO, 2018, 2019b), the aviation industry can still benefit significantly from the application of research results in directions for teaching and high-stakes testing.

This paper thus aims to address such needs by highlighting the interface of findings from a concluded research (MONTEIRO, 2019a), thereafter called Study 1, and results from the investigation described in this paper, thereafter called Study 2. The main objective is to demonstrate the many complex features that form the communicative exchanges in this highly technical domain, and to suggest how these findings can be integrated to better align teaching and testing practices with current understandings of language use and with the requirements of the TLU domain. As a result, the research questions that guide this study are as follows:

RQ1) How do the factors that may impact RT communication, as perceived by Study 2 participants and identified in the analysis of a RT scenario, corroborate the components of the matrix that maps the construct of aeronautical communication, validated in Study 1 ?

RQ2) How can findings from Study 1 and 2 inform teaching and high-stakes testing aiming to improve communicative competence above a purely linguistic level? 
Research reported in this paper draws on empirical data from Study 1 and Study 2 and aims to provide a more comprehensive analysis of the phenomenon being investigated. Details of the methods used in the two studies will be presented separately in the next section.

\section{Method}

\subsection{Study 1}

Study 1 corresponds to the second phase of Monteiro's (2019a) multiphase mixed methods research, which included the development and validation of the matrix of construct specification. Although it does not constitute the primary focus of this paper, findings from this research will be used to support results from Study 2, described in Section 4.2.

With the objective of specifying the construct of aeronautical radiotelephony communication, this qualitative investigation comprised four sequential steps: i) a systematic review of theoretical and empirical research in the domains of Aviation English, English as a lingua franca, Intercultural awareness/competence, and Interactional competence; ii) the design of theoretical models of language use specific to the occupational context of pilot-ATCO communications; iii) matrix development - the specification of a framework that maps the constructs considered to be relevant to the target language use (TLU) domain; and iv) matrix validation - based on aviation stakeholders' perceptions of the communicative needs of pilots and ATCOs in the multicultural context of international radiotelephony. For the matrix validation, participants were recruited in two international aviation English conferences, one in Croatia and the other in Brazil. Conference organizers were contacted in advance of the events and granted approval. Ethics clearance for this phase of the study was granted by Carleton University Research Ethics Board on April 20, 2017. Table 1 provides details of the method used in the matrix validation.

Table 1. Method used in the matrix validation

\begin{tabular}{|c|c|c|c|}
\hline Participants & Instruments & Procedures & Analysis \\
\hline $\begin{array}{l}128 \text { aviation stakeholders: } \\
>\quad 20 \text { NSs }+108 \text { NNSs } \\
\text { of English } \\
>\quad 52 \text { males }+76 \\
\text { females } \\
>\quad 22 \text { pilots } \\
21 \mathrm{ATCOs} \\
36 \mathrm{AE} \text { teachers } \\
36 \mathrm{AE} \text { examiners } \\
6 \text { AE researchers } \\
6 \text { regulators } \\
1 \text { AE curriculum } \\
\text { developer }\end{array}$ & $\begin{array}{l}\text { Focus group } \\
\text { discussions triggered } \\
\text { by six scenarios of } \\
\text { authentic } \\
\text { international RT } \\
\text { communication (one } \\
\text { scenario for each } \\
\text { group) and a set of } \\
\text { six questions }\end{array}$ & $\begin{array}{l}\text { Intra-group discussions } \\
-26 \text { groups: } \\
\text { (audio-recorded and } \\
\text { (ranscribed) } \\
\text { Inter-group discussions } \\
\text { (audio-recorded and } \\
\text { transcribed) }\end{array}$ & $\begin{array}{l}\text { Nvivo software } \\
\text { 1 st cycle: Provisional } \\
\text { Coding (dimensions of } \\
\text { AW, K, S, AT) } \\
\text { Inter-coder reliability } \\
\text { 2nd cycle: Provisional } \\
\text { Coding (construct } \\
\text { components) }\end{array}$ \\
\hline
\end{tabular}


Source: Monteiro (2019b, p. 88)

Not only did the last step give voice to domain experts, but it also used as triggers to elicit their comments authentic scenarios of international RT communication between speakers of different language and cultural backgrounds.

\subsection{Study 2}

Study 2 was conducted in two phases: the first phase by the second author alone and the second phase by both authors of this paper.

\subsubsection{Phase 1}

The first phase of Study 2 aimed to expand on the results of the pilot study (BULLOCK, 2018) described in the Literature Review, using Subject Matter Experts (SMEs) as informants during Language Assessor refresher training workshops delivered by a national aviation authority in Europe. The study comprised 15 pilots (commercial pilots and airline transport pilots) and three ATCOs, all with many years working in an operational aviation environment, and all rated for their English language proficiency at ICAO level 5 or 6 . They all had notable experience carrying out assessments for English language proficiency tests for this national authority, based on a testing system developed using ICAO recommendations and European Aviation Safety Agency (EASA) legislation. Participants were thus selected on the basis of a large degree of homogeneity of their wide operational background and their experience of dealing first-hand with the ICAO LPRs. Between July 2019 and January 2020, data collection continued during each successive Assessor Refresher training session. This provided further evidence to help support a greater awareness and understanding of all the key factors that impact pilot/ATCO communications, not only language in isolation. It also offered some evidence that criticism of the LPRs was, to a certain extent, justified.

A qualitative methodology was used since this was the easiest and quickest way to gather data in already prescribed training situations where SMEs would be present. Participants were invited to brainstorm the question "What factors affect pilot/ATCO communication?", using an online tool called Mentimeter, which allows participants to use their portable electronic devices to connect to an ongoing presentation, where they can answer questions or provide comments anonymously. Table 2 provides an overview of the participants' sample, instruments, procedures and data analysis. 
Table 2. Method used in Study 2 - Phase 1

\begin{tabular}{|c|c|c|c|}
\hline Participants & Instruments & Procedures & Analysis \\
\hline $\begin{array}{l}18 \text { aviation stakeholders: } \\
>\quad \text { All NNSs of English } \\
>\quad 16 \text { males }+2 \text { females } \\
>\quad 15 \text { pilots } \\
\quad 3 \text { ATCOs }\end{array}$ & $\begin{array}{l}\text { Participants } \\
\text { brainstormed the } \\
\text { question "what } \\
\text { factors affect } \\
\text { pilot/ATCO } \\
\text { communication". } \\
\text { They were } \\
\text { encouraged to offer } \\
\text { as many individual } \\
\text { elements as possible. }\end{array}$ & $\begin{array}{l}\text { Input all ideas into } \\
\text { Mentimeter software } \\
\text { through personal } \\
\text { devices. } \\
\text { Inter-group discussions } \\
\text { on reasons why } \\
\text { elements added and the } \\
\text { role each one plays. } \\
\text { Raw data was saved and } \\
\text { downloaded from the } \\
\text { Mentimeter site }\end{array}$ & $\begin{array}{l}\text { Excel spreadsheet of all } \\
\text { data downloaded from } \\
\text { Mentimeter member page. } \\
\text { 1st cycle: Provisional } \\
\text { Coding into supra- } \\
\text { environmental groups as } \\
\text { affective categories } \\
\text { 2nd cycle: Final Coding } \\
\text { into generalised Coded } \\
\text { Factors and then grouped } \\
\text { into Coded Domains. }\end{array}$ \\
\hline
\end{tabular}

The participants provided 108 individual response factors, which featured the key elements that could affect the quality of pilot/ATCO communication, e.g.: standard phraseology, cockpit noise, VHF quality, congested frequency, etc. Each key element was then put into a supra-elemental group labelled Coded Factors, of which there were 38. Coded Factors attempted to group together raw elements into common element environments using ideas from the Eurocontrol training portal Skybrary. Two specific $\begin{array}{llllll}\text { categories } & \text { were } & \text { used } & - & \text { Air } & \text { Ground }\end{array}$ (https://www.skybrary.aero/index.php/Category:Air_Ground_Communication) and Operators Guide to Human Factors in Aviation (OGHFA - https://www.skybrary.aero/index.php/Portal:OGHFA). Given examples of raw data elements cultural differences and local knowledge were attributed to 'Intercultural Competence'. Mental state and mood were attributed to 'Attention and Vigilance'. Operational factors such as SOPS and Rules were categorised under 'Procedures', and so on. The single most cited Factor was 'Radio equipment quality' with 12 examples. Once this had been completed, the Coded Factors were attributed to Coded Domains to which the factors could then be attributed as an over-arching reference.

\subsubsection{Phase 2}

In order to validate further the results from Phase 1 and offer some evidence to support the emerging theory, the data was then cross-referenced, in Phase 2, with a real-life non-routine situation within the context of international radiotelephony. Thus, an analysis of the audio recording and transcript of an authentic RT scenario ${ }^{4}$ was carried out, using the Coded Factors and Coded Domains obtained in Phase 1. Table 3 provides more details of the method used in this Phase of the study.

Table 3. Method used in Study 2 - Phase 2

\footnotetext{
${ }^{4}$ Publicly available at http://www.youtube.com/watch?v=1ICb8p9SvvM . 


\begin{tabular}{|l|l|l|}
\hline \multicolumn{1}{|c|}{ Instruments } & \multicolumn{1}{c|}{ Procedures } & \multicolumn{1}{c|}{ Analysis } \\
\hline $\begin{array}{l}\text { An authentic scenario of a } \\
\text { non-routine, intercultural } \\
\text { RT communication } \\
\text { between pilots flying } \\
\text { "Swiss 1311" and ATCO in } \\
\text { St. Petersburg, Russia }\end{array}$ & $\begin{array}{l}\text { Listen to the recording } \\
\text { Organize the transcript for coding (unit } \\
\text { of analysis - the utterance) }\end{array}$ & $\begin{array}{l}\text { Code independently } \\
\text { Conduct member-checking between } \\
\text { coders }\end{array}$ \\
\hline
\end{tabular}

In the next section, findings will be presented for each Study and corresponding Phase, and discussions will focus initially on what was revealing within each one.

\section{Findings and partial discussions}

\subsection{Study 1}

In the validation of the matrix of construct specification (MONTEIRO, 2019a) - a 4 x 4 table, covering the dimensions of awareness, knowledge, skills and attitudes, and the domains of Aviation English, English as a lingua franca, intercultural awareness and interactional competence - the coding process of participants' comments from focus group discussions disclosed that most components of the construct included in the draft matrix (from the review of theory and research) were confirmed by aviation stakeholders. Those components that have not appeared in the initial step but emerged from participants' discussions, were included in the corresponding matrix cell, while a few ones not explicitly mentioned were removed.

By considering the number of coding references for each component of the construct separately, it was possible to organize them within each cell from the highest to the lowest number of references. As a result, the four most cited components of each cell of the matrix were identified and included in the final matrix of construct specification. Table 4 presents the final matrix, showing the confirmed components in normal font, the emergent components in bold, and the individual numbers of coding references in parentheses. 
Table 4. Final matrix of construct specification

\begin{tabular}{|c|c|c|c|c|}
\hline \multicolumn{5}{|c|}{ Construct definition within the aviation radiotelephony domain } \\
\hline & Awareness & Knowledge & Skills & Attitudes \\
\hline $\begin{array}{c}\text { Aviation } \\
\text { English }\end{array}$ & $\begin{array}{l}\text { - situational awareness (67) } \\
\text { - group identities and } \\
\text { authority gradients in aviation } \\
(50) \\
\text { - rules of use that characterize } \\
\text { the domain (27) } \\
\text { - threats presented by cross- } \\
\text { cultural communications (19) } \\
\end{array}$ & $\begin{array}{l}\text { - background knowledge (rules and } \\
\text { procedures) (78) } \\
\text { - standard phraseology (36) } \\
\text { - plain English for the specific purpose of } \\
\text { aeronautical RT communications (26) } \\
\text { - communication as a Human Factor (6) }\end{array}$ & $\begin{array}{l}\text { - Crew Resource Management (CRM) } \\
(55) \\
\text { - language proficiency (ability to use the } \\
\text { language) (45) } \\
\text { - communicate effectively in routine and in } \\
\text { highly unpredictable situations (39) } \\
\text { - conflict management (12) }\end{array}$ & $\begin{array}{l}\text { - professional tone and attitude (195) } \\
\text { - compliance with prescribed rules and } \\
\text { procedures (e.g. use of phraseology, } \\
\text { read back/hear back) (193) } \\
\text { - assertiveness (87) } \\
\text { - clarity, conciseness and correctness } \\
\text { (37) }\end{array}$ \\
\hline $\begin{array}{l}\text { English as a } \\
\text { lingua } \\
\text { franca }\end{array}$ & $\begin{array}{l}\text { - challenges faced by speakers of } \\
\text { EFL and interlocutors' possible } \\
\text { linguistic difficulties ( } 34 \text { ) } \\
\text { - difficulty presented by the use } \\
\text { of jargon, idioms, slang and } \\
\text { colloquialisms (17) } \\
\text { - the need to speak English as a } \\
\text { lingua franca (17) } \\
\text { - different varieties of English } \\
\text { and speech communities (9) }\end{array}$ & $\begin{array}{l}\text { - nuances of the language (5) } \\
\text { - language as a social practice (4) } \\
\text { - one's own communicative style and the } \\
\text { problems it could pose to ELF interactions (3) } \\
\text { - characteristics of one's L1 phonology that } \\
\text { may influence English pronunciation (2) }\end{array}$ & $\begin{array}{l}\text { - adjust and align to different } \\
\text { communicative systems (new patters of } \\
\text { phonology, syntax, discourse styles) (23) } \\
\text { - eliminate ambiguous expressions and } \\
\text { sentence patterns (21) } \\
\text { - adapt linguistic forms to the } \\
\text { communicative needs at hand (20) } \\
\text { - self-repair, rephrase, paraphrase, and } \\
\text { clarify (13) }\end{array}$ & $\begin{array}{l}\text { - patience (68) } \\
\text { - collaborative behavior (45) } \\
\text { - avoidance of any kind of superiority of } \\
\text { one variety over another (39) } \\
\text { - tolerance (12) } \\
\text { - openness and humility to negotiate } \\
\text { differences (12) }\end{array}$ \\
\hline $\begin{array}{l}\text { Intercultural } \\
\text { Awareness/ } \\
\text { Competence }\end{array}$ & $\begin{array}{l}\text { - how the cultural background of } \\
\text { participants can impact the } \\
\text { complex and dialogic nature of } \\
\text { their communications (58) } \\
\text { - power distance (27) } \\
\text { - gender expectations (17) } \\
\text { - face concern (12) }\end{array}$ & $\begin{array}{l}\text { - what is involved in intercultural interaction } \\
\text { (11) } \\
\text { - potential threats posed by intercultural } \\
\text { communications (11) } \\
\text { - different cultural frames of reference } \\
\text { (communication style, conflict management, } \\
\text { face-work strategies, etc) (10) } \\
\text { - how social groups and identities function (3) }\end{array}$ & $\begin{array}{l}\text { - move beyond cultural stereotypes and } \\
\text { generalizations (11) } \\
\text { - engage with and negotiate sociocultural } \\
\text { differences (5) } \\
\text { - engage with politeness conventions (5) } \\
\text { - accommodate to difference and to } \\
\text { multilingual aspects of intercultural } \\
\text { communication (4) }\end{array}$ & $\begin{array}{l}\text { - politeness }(90) \\
\text { - willingness to cooperate (25) } \\
\text { - respect (20) } \\
\text { - readiness to suspend disbelief about } \\
\text { other cultures and belief about one's } \\
\text { own }(9) \\
\text { - willingness to relativize one's own } \\
\text { values, beliefs, behaviors }(9)\end{array}$ \\
\hline $\begin{array}{l}\text { Interactional } \\
\text { Competence }\end{array}$ & $\begin{array}{l}\text { - shared responsibility for } \\
\text { successful communication (5) } \\
\text { - discourse as co-constructed } \\
\text { among participants (3) } \\
\text { - communication as 'a two-way } \\
\text { negotiative effort' (1) }\end{array}$ & $\begin{array}{l}\text { - register specific to the practice (10) } \\
\text { - an appropriate participation framework (3) } \\
\text { - the processes we go through to solve } \\
\text { communication issues (1) }\end{array}$ & $\begin{array}{l}\text { - deal adequately with apparent } \\
\text { misunderstandings, by checking, confirming } \\
\text { and clarifying ( } 44 \text { ) } \\
\text { - use of communicative/interactional } \\
\text { skills (36) } \\
\text { - accommodate to the constraints of the } \\
\text { context and perceived ability of the hearer } \\
\text { (20) } \\
\text { - declare non-understanding (9) }\end{array}$ & $\begin{array}{l}\text { - avoidance of intimidation and } \\
\text { threatening behavior }(10) \\
\text { - cooperation (9) } \\
\text { - tolerance }(6) \\
\text { - flexibility (4) }\end{array}$ \\
\hline
\end{tabular}

Source: Adapted from Monteiro (2019a, p. 220) 
The sum of coding references for the construct components in the final matrix is presented in Table 5 , considering the intersection of each dimension with the four domains of interest. It indicates the prevalence of the Aviation English domain and attitude, as the dimension with more coding references.

Table 5. Weighting of construct components included in the final matrix

\begin{tabular}{|c|c|c|c|c|c|}
\hline & AW & K & S & AT & Total \\
\hline AE & 163 & 146 & 151 & 512 & 972 \\
\hline ELF & 77 & 14 & 77 & 176 & 344 \\
\hline ICA & 114 & 35 & 25 & 153 & 327 \\
\hline IC & 9 & 14 & 109 & 29 & 161 \\
\hline Total & 363 & 209 & 362 & 870 & 1804 \\
\hline
\end{tabular}

Source: Monteiro (2019a, p.221)

Findings also revealed the components of the construct that were mentioned by the highest number of focus groups, namely background knowledge, followed by professional tone and attitude and compliance with prescribed rules and procedures (e.g., use of phraseology, readback/hear back), which confirm results from previous studies (e.g., DOUGLAS, 2014; ESTIVAL, 2018; KIM, 2012; KIM, 2018; KNOCH, 2014).

\subsection{Study 2 - Phase 1}

Coding of participants' response factors that led to their categorization into Coded Factors and Coded Domains is presented in Table 6. Among the eight coded domains, linguistic (25) and operational environment (25) provided the most factors, followed by human factors (19), operational knowledge (15), and technical (12).

The data is quite revealing in that out of 108 response factors, only $30(27.8 \%)$ were categorised as 'linguistic' or 'socio-linguistic', against $72.2 \%$ categorised as non-linguistic. Of these, operational domains including knowledge, environment and technical accounted for 52 factors (48.14\%), whilst human domains - human factors and cultural accounted for 25 (23.15\%). 
Table 6. Coded Factors and Coded Domains attributed to Study 2 participants' responses

\begin{tabular}{|c|c|c|}
\hline $\begin{array}{l}\text { Number of } \\
\text { Response } \\
\text { Factors }\end{array}$ & Coded Factor & Coded Domain \\
\hline 3 & Cultural background & \multirow[t]{3}{*}{ Cultural } \\
\hline 2 & Intercultural competence & \\
\hline 1 & Regional influence & \\
\hline 1 & Discipline & \multirow{4}{*}{$\begin{array}{l}\text { HF - Personal Actions and } \\
\text { Behaviours }\end{array}$} \\
\hline 2 & Error management & \\
\hline 1 & Interruptions and Distractions & \\
\hline 1 & Monitoring skills & \\
\hline 3 & Attention and Vigilance & \multirow[t]{5}{*}{ HF - Personal influences } \\
\hline 5 & Fatigue manifestations & \\
\hline 1 & Mental state & \\
\hline 1 & Pilot judgement and expertise & \\
\hline 4 & Stress and Stress management & \\
\hline 3 & Accent & \multirow[t]{11}{*}{ Linguistic } \\
\hline 3 & Enunciation & \\
\hline 2 & Fluency & \\
\hline 1 & Intonation & \\
\hline 7 & Language Proficiency & \\
\hline 1 & Linguistic knowledge & \\
\hline 1 & Listening & \\
\hline 4 & Pronunciation & \\
\hline 1 & Speaking & \\
\hline 1 & Structure & \\
\hline 1 & Vocabulary & \\
\hline 6 & Busy frequency & \multirow[t]{9}{*}{ Operational Environment } \\
\hline 2 & Context & \\
\hline 1 & Expectations & \\
\hline 3 & Experience & \\
\hline 1 & Large amount of traffic & \\
\hline 5 & Noise & \\
\hline 1 & Prioritizing & \\
\hline 3 & Weather & \\
\hline 3 & Workload & \\
\hline 7 & Procedures & \multirow[t]{2}{*}{ Operational Knowledge } \\
\hline 8 & Technical knowledge & \\
\hline 1 & Code switching & \multirow[t]{3}{*}{ Sociolinguistic } \\
\hline 2 & Knowledge & \\
\hline 2 & L1 use & \\
\hline 12 & Radio equipment quality & Technical \\
\hline
\end{tabular}

The data provides evidence that, amongst the responses of the SMEs, i.e: those professionals working and communicating regularly in an operational environment, there is an awareness of many contributory factors in pilot/ATCO communication that can not solely be attributed to language in isolation. This data corroborates the ideas of Kim and Elder (2009, 2015) and Kim (2018), and provides further insights into why the aforementioned disconnect between pilots/ATCOs and testing systems could be so evident. If assessment of language proficiency for aeronautical communication does not take into account 
all the factors that affect the communicative process, then face validity (ALDERSON; CLAPHAM; WALL, 1995 ) - confidence in, and respect for, the test instrument amongst test takers - is going to be low and the test instrument is unlikely to give a fair assessment and, by default, a valid and useful result for all stakeholders.

\subsection{Study 2 - Phase 2}

The analysis of a real-life non-routine situation within the context of international radiotelephony, by applying the list of Coded Factors and Coded Domains presented in Table 6, indicates that a lot more than linguistic factors played a role in this communicative event. The complete analysis of the transcript is presented in the Appendix. The Coded Domains that appeared in this particular scenario, from the most cited to the least, were: Linguistic - 25; Operational Knowledge - 17; Operational Environment - 14; HP Personal influences - 8; HF - Personal Actions and Behaviours - 6; Technical - 4; and Sociolinguistic - 1 .

First, in relation to the linguistic factors, it is worth pointing out problems associated with listening comprehension, strong accents, bad enunciation, language structure (e.g., line 29, we have two engine problems), use of wrong prepositions that changed the meaning of the sentence (e.g., line 52, information from your company instead of 'about' your company), choice of ambiguous expressions (e.g., line 15, Swiss 1311, expect, which could be interpreted as 'Standby' or 'it should be OK'), lack of appropriate vocabulary (e.g, line 42, we need a tractor - more commonly called a 'tug' and line 43, a car sent for you - ambiguous term for vehicle). All of them had a direct impact on how quickly and accurately the participants understood the message, many times requiring a lot of clarification and negotiation, which prolonged this exchange much more than necessary. The code switching from English to Russian in the same radio frequency (e.g., line 30), also made the communication even more challenging.

These linguistic issues, however, were not the only source of barriers to a more effective communication. In many instances, both the pilot of Swiss 1311 and the Russian ATCO used improper phraseology when there was a standard expression to convey an idea or situation (e.g., line 17, you ... catch ...bird?, and line 5, Swiss 1311, identify... What kind of problem?), or even demonstrated lack of procedural and system knowledge (e.g., line 54, I don't know how can I connect with your representative). Factors related to the operational environment, such as an increase in workload due to the emergency situation requiring a change in priorities (e.g., line 12, bird strike...bird strike, moving from extended communication to critical communication) and a lot of background noise (e.g., lines 37, 43, 46 and 48) were also exacerbated by expectations not being met (e.g., line 42, how can we wait?, and line 47, No!! I need a tractor). 
In addition, unexpected and emergency situations may also impact the levels of attention and monitoring skills (e.g., in lines 8 and 9 the pilot's readback error was not detected by the ATCO), may affect the mental state and situational awareness of interlocutors (e.g., 30, 28 problems?), and may also have an influence on the way each one manages stress in the communicative event (e.g., lines 43, 45 and 47). Moreover, in this interaction we can find a few exchanges that do not seem very logical (e.g., from line 35 to 41, the utterances lack a meaningful sequence of ideas and responses), probably due to lack of comprehension and interactional skills, such as initiating and maintaining dialogue. Additionally, the audio recording of this scenario allowed us to perceive how challenging the communication can become as a result of interferences related to radio equipment quality, thus affecting the readability of the messages.

On a final note, although the cultural factors were not explicitly coded in this transcript, it is important to emphasize that communication is never neutral and that in any type of interaction, "whether judged important or not, culture and identity are always present” (BAKER, 2017, p. 27). Baker explains that there is no such thing as neutral communication, for "all communication, intercultural or otherwise, involves participants whose identities will be present in the interaction in one way or another" (p. 27). Hofstede (1991) also argues that each professional belongs to a number of social groups or cultures, "carrying several layers of mental programming within themselves, corresponding to different levels of culture" (p. 10), such as national, regional, gender, generation, social class, and organizational or corporate levels. Therefore, Monteiro (2019a) argues that "the combination of cultural identities, or the conflict among them, may influence what people say, how they say it, the responses they expect, and how they react to previous utterances" (p. 144).

In conclusion, the analysis of the non-routine RT scenario (Study 2 - Phase 2) not only provided evidence to support the emerging theory from aviation experts' opinions (Study 2 - Phase 1), but also confirmed the complexity of this context of language use. Aeronautical radiotelephony is a case of highly technical and distinctive use of the language, which requires not only language ability, but also specific purpose background knowledge combined with an awareness of the multiple factors that may impact the outcomes of pilot/ATCO communications.

\section{Results and discussions}

Integration of findings from Study 1 and Study 2 is presented and discussed in this section in relation to each research question. 
In response to RQ1, the factors that may impact RT communication, as perceived by Study 2 participants (see Table 6) and identified in the analysis of the RT scenario (see Appendix), corroborate the components of the matrix that maps the construct of aeronautical communication (Study 1) in a number of ways. First and foremost, it is important to underscore that the matrix was built based on domain experts' perceptions of the competencies pilots and ATCOs must acquire in order to communicate effectively in the multicultural context of aeronautical radiotelephony communication. Thus, it can be said that an aviation professional who develops these construct components (outcome of Study 1) should be better equipped to deal with communication breakdowns caused by the factors that are likely to have an impact on RT communication (outcome of Study 2).

Within the first row of the matrix, which specifies the construct associated with the Aviation English domain, a correspondence is clearly noted. Not surprisingly, as they represent the specific domain of aviation, most components have already been discussed in the analysis of the RT scenario and play a crucial role in the communication success. For instance, situational awareness (e.g., lines 30 and 46), knowledge of rules and procedures (e.g., lines 1, 46, 52, 54), communication as a Human Factor (e.g., lines 6, 8, 29, 36), compliance with standard phraseology (e.g., lines 3-5, 15, 28, 46), language proficiency (e.g., lines 11, 17, 19-21, 39), and the need to communicate effectively in routine and highly unpredictable situations (e.g., lines 1 and 12).

Moreover, the English as a lingua franca domain encompasses features associated with the challenges faced by speakers of English as a Foreign Language (EFL), in terms of pronunciation, accent and enunciation (e.g., lines 9, 13, 31), the need to eliminate ambiguous expressions and sentence patterns (e.g., lines 15, 20, 29, 43), and also to rephrase, paraphrase and clarify (e.g., line 45). In response to the interlocutor's possible linguistic difficulties, it is also paramount that participants demonstrate collaborative behavior and tolerance (e.g., lines 28, 55).

As pilot/ATCO radiotelephony communications are embedded within a multicultural and multilingual context, professionals should be aware of the various ways the cultural background of interlocutors impacts their radio exchanges. Study 2 respondents considered this as an important issue and, at the same time, mentioned the need to develop intercultural competence. From the components of the construct described in the Intercultural Awareness/Competence domain, we can say that being able to accommodate to difference and to multilingual aspects of intercultural communication, combined with the knowledge that participants possess different communicative styles, conflict management, and face-work strategies, would have helped the Swiss 1311 pilot and the Russian ATCO to overcome the difficulties in their interaction. 
Finally, with reference to the Interactional Competence domain, it was noted that in the non-routine scenario analysed, many times both participants resorted to the skills of checking, confirming and clarifying to deal with apparent misunderstandings (e.g., lines 6, 10, 18, 30, 40, 50). Other times, it was necessary to accommodate to the constraints of the context and perceived ability of the hearer by slowing down the speed of delivery (e.g., lines 42, 45). However, the pilot's interaction with Pulkovo Ground (e.g., lines 35 41) revealed a lack of awareness that previous messages have not been understood and the absence of strategic skills to handle the communication breakdown.

It has been evident for some years that communicative skills rely on more than simple language and that defining factorial elements is extremely complex. It has also been discussed that in specific purpose domains the requirement to replicate all elements of the TLU communicative process in order to truly teach and assess the required communicative ability of test takers is primordial, although with few purposeful examples to really illustrate how this could be done. The findings in this paper therefore provide some initial evidence of how additional communicative factors could be taken into account to more accurately replicate the features of real-life communication, of which linguistic factors are only a part. It is suggested, therefore, that such factors be considered for integration into teaching and high-stakes testing to widen and improve the communicative competence of pilots and ATCOs beyond the constraints of a language only approach. Therefore, drawing on what Study 1 and 2 yielded as relevant to this occupational context, RQ2 is addressed below, with a discussion of how these research findings can inform such teaching and highstakes testing practices.

\subsection{Directions for teaching}

The studies presented thus far provide important insights into what constitutes aeronautical radio communication between pilots and ATCOs. It provides clear evidence that, as Kim (2018) alluded to, such communication is an extremely complex mixture of factors, of which language is just one. These findings therefore have extremely important implications for aviation personnel when learning how to communicate in operational situations. If language is taught in isolation with little reference to real-world communicative factors, as shown in this paper, then pilots and ATCOs will be much less aware of causal factors inherent during communication breakdowns, as well as how to deal with such to ensure communication is as efficient and as effective as possible. Furthermore, if those responsible for delivering training have little operational knowledge, or have not themselves been specifically trained to teach language for aviation communication, then the danger is that the awareness of what constitutes real-life communication skills will be lacking in any language training. The consequence of this is that personnel will not be trained to 
understand and use the full range of communication skills required for their operational roles thus creating a weak and dangerous link in the communication process.

All of this runs contrary to the aims and recommendations of the ICAO LPRs, which were implemented to improve communication between pilots and ATCOs (ICAO, 2010). If not all of the required communicative skills are taken into account for teaching and testing, then progress in improving communication will not be as efficient and as effective as it should be for safe flight operations. In an operational environment that is forecast to become more and more complex in the near future, this surely has serious implications for aviation safety.

A key policy priority should therefore be to research and develop the following two proposals as a remedial process:

- A global curriculum should be professionally developed for teaching language in aviation communication for pilots and ATCOs. Language for aeronautical communication should no longer be taught in isolation or seen simply as an "aviation English" lesson. Curricula should allow for modifications to address regional and operational specificities;

- An internationally recognized training programme for teachers and instructors required to teach language as part of the aeronautical communication process should also be professionally developed. This development should be overseen and delivered by both subject matter experts and language experts, as well as those qualified and experienced in instructor training. Stakeholders responsible for hiring such trainers and instructors would ensure that all instructors are thus certified.

In support of the above proposals, it is recommended that consideration be given to including the elements from pilot/ATCO communication listed below, identified in this study, as integral components of both the curriculum and instructor training programme. Further research regarding the role of these elements should be undertaken in order to identify how they specifically affect the real-life communication process between pilots and ATCOs.
i). Intercultural awareness
ii). Sociolinguistic influences
iii). Human factors - Personal actions and behaviours
iv). Human factors - Personal influences
v). Communication and language in the operational environment 
vi). Communication and language in operational knowledge

vii). Technical issues likely to affect communication

viii). Understanding the listener - roles and environment.

In addition, the following linguistic elements should be considered as integral to any language training and teacher training curriculum for this specific purposes domain:

- communicative methodology teaching and training;

- interactive activities specific to the communication process;

- training of pragmatic and strategic communication skills;

- interplay of standard phraseology, technical plain language and general purpose language (including: the roles of functional language and technical collocations and compounds in context);

- code switching;

- accommodation to situational and perceived listener constraints.

\subsection{Directions for testing}

When referring to language assessments for professional purposes (LAPPs), Knoch \& Macqueen (2020) mention the need to reduce 'language-associated risk', as explained below:

The language proficiency of professionals is most often assessed as a part of a formal process of reducing language-associated risk to the public (e.g. patients, co-workers, passengers, clients) through ensuring that the professional person's capacity to communicate in professional activities is sufficient for maintaining a reasonable likelihood of public safety and well-being. For example, a language test may be used to determine whether a pilot's Aviation English is proficient enough to carry out interactions with air traffic control so that there is little likelihood of adverse events caused by miscommunication. In this case, the language risk has an obvious physical implication. (KNOCK; MACQUEEN, 2020, p. 16)

Decisions made on the basis of pilots' and ATCOs' test results have high-stakes for all involved. Therefore, the development of tests for this professional purpose should follow a rigorous process, with the involvement of different stakeholder groups in all phases, and subject to revisions in a systematic and iterative way. As Messick (1994, p. 16) describes, this process would probably begin "by asking what complex of knowledge, skills, or other attributes should be assessed ... Next, what behaviors or performances should reveal those constructs, and what tasks or situations should elicit those behaviors?".

Study 1 findings represent what all domain stakeholders, not only pilots and ATCOs, but also teachers, examiners, regulators and researchers in the field of aeronautical English, valued in terms of what should be assessed. Drawing on this information, test developers would then design tasks that generate the 
evidence needed to make inferences from test performance based on the constructs of interest. Monteiro (2019a) provides a detailed account of the way this was done in the development and pilot testing of a roleplay task to assess the communicative abilities of pilots. Her findings suggest that "the aviation radiotelephony-specific communicative construct, as opposed to a language proficiency construct alone, can be operationalized as test tasks" (p. 346).

In addition, Study 2 - Phase 1 results revealed what factors were considered critical as potential causes of misunderstanding in RT communication, whereas Study 2 - Phase 2 findings demonstrated, within the context of language use, how those factors operated and sometimes overlapped, increasing the likelihood of communication breakdowns. In this respect, Knoch and Macqueen (2020, p. 89) argue that analyzing the communication problems that test takers experience in the target language use (TLU) domain is very important "as this can help narrow down the potential tasks that were identified in a domain analysis when the test blueprint ${ }^{5}$ is developed. Tasks that pose particular risks can then be the focus for the development of the test blueprint". Such tasks could require test takers to: communicate in non-routine situations; detect and resolve misunderstandings; negotiate meaning when ambiguous; and declare nonunderstanding by asking for clarification, to name a few.

Throughout the process of task design in LSP testing, test developers need to make choices and decisions related to the issues of authenticity of tasks, specificity of content and the interaction between language knowledge and specific purpose content knowledge (DOUGLAS, 2001; KNOCH; MACQUEEN, 2020). Regarding the latter, interrelated findings reported in this paper substantiate this idea, as demonstrated by the number of coding references for the construct components related to the Aviation English domain (Study 1), and also the number of factors coded under the domain of Operational Knowledge (Study 2). This brings important implications for language testing and assessment in the aeronautical RT communication context. As O’Sullivan (2012, p. 74) points out, “the extent to which LSP assessment developers include the test taker's background knowledge of the target domain in their construct definition is a key element of the resulting assessment's interactional authenticity, since it is this aspect of a test task that makes it specific in the first place".

\section{Conclusions}

\footnotetext{
${ }^{5}$ Test blueprint can be understood as a synonym for test specifications. Fulcher and Davidson (2007, p. 36) explain that test specifications "are generative blueprints or plans for a specific test", containing details for the creation of tasks and the rationale behind them.
} 
The main objectives of this paper were, firstly, to demonstrate the many complex features that form the communicative exchanges in the highly technical and professional domain of aeronautical communication. Secondly, it was to suggest how findings from two studies could be integrated to better align teaching and high-stakes testing with current understandings of language use in communication from the TLU domain. Results underlined the importance of giving voice to different stakeholder groups, of exploring authentic scenarios of pilot/ATCO radio communications, and above all, confirmed the need to move from a language-only approach to a broader view of professional communicative competence for aeronautical communications. This suggested view takes into account the role of background and professional knowledge, as well as all factorial elements, and situational awareness of the operational environement. Furthermore, it encompasses the role of intercultural awareness, collaborative efforts, negotiation, accommodation, co-construction, and shared responsibility for effective communication, all derived from an understanding of language as a social practice. It also offers the possibility of addressing longstanding concerns about the current ICAO testing policy (ICAO, 2010) which automatically considers L1 and expert speakers of English as competent to communicate in such a technical, complex, and multicultural occupational context, with little or no formal testing.

Considering the critical role of communication in aviation safety, and the fact that international radiotelephony exemplifies a specialized and professional multicultural context of language use, pilots and ATCOs need to be aware of the multiple factors that impact communications. To this end, language teaching curricula and materials need to be appropriately adapted and developed for learners to acquire the range of knowledge, skills and attitudes they need to communicate effectively and efficiently in their operational domain. Furthermore, in order to be sure that an operational level of all appropriate communicative competencies can be evaluated, thus allowing valid inferences of test scores to be made, high-stakes test developers must demonstrate that all such multiple factors and competencies have been integrated into their testing constructs and test tasks.

In summary, these findings underscore, firstly, the critical importance of a much more appropriate and effective standard for the training of teachers of aviation language, which includes a wider appreciation of all the communicative skills and factorial elements of the operational environment. Secondly, it clearly demonstrates the fact that an increase in the levels of assessment literacy for all those involved in the highstakes assessment of pilots and ATCOs must be addressed. Only when both these elements have been appropriately addressed, will teaching curricula and assessment instruments provide results that allow it to be said, with some degree of confidence, that pilots and controllers worldwide are better able to achieve and 
maintain appropriate and effective communicative skills and, as a consequence, a safer operational environment.

\section{References}

ALDERSON, C. J.; C. CLAPHAM; D. WALL. 1995. Language test construction and evaluation. Cambridge: Cambridge University Press.

ARAGÃO, B. F. 2018. O uso de critérios autóctones no contexto aeronáutico: Contribuições para uma nova escala de proficiência para controladores de tráfego aéreo. In: SCARAMUCCI, M. V. R.; P. TOSQUI-

LUCKS; S. M. DAMIÃO (Eds.). Pesquisas sobre inglês aeronáutico no Brasil. Campinas: Pontes. p. $243-$ 269.

BAKER, W. 2017. English as a lingua franca and intercultural communication. In JENKINS, J.; W. BAKER; M. DEWEY (Eds.). The Routledge handbook of English as a lingua franca. New York: Routledge. p. 25-36, e-book.

BOROWSKA, A. 2015. Do expert speakers need to practice a language? In BOROWSKA, A.; A. ENRIGHT (Eds.). Changing perspectives on Aviation English training. Warsaw: Uniwersytet Warszawski. p. 61-72.

BULLOCK, N. 2015. Defining meaningful material for the teaching of English for aeronautical communications. In BOROWSKA, A.; A. ENRIGHT (Eds.). Changing perspectives on Aviation English training. Warsaw: Uniwersytet Warszawski. p. 35-45. . 2018. Evolving teacher training programmes through integrating contextual factors for language learning as part of aeronautical communication. In ROBERTS, J.; D. ESTIVAL (Eds.). The Proceedings of the International Civil Aviation English Association (2018) Conference. Daytona Beach/FL, USA. p. 67-83. Available at $<$ https://commons.erau.edu/icaea-workshop/2018/proceedings/1 > . Access: 25 apr. 2019. 2019. Validating new perspectives and methodologies for learning and teacher training in English for aeronautical communications. In PAPADIMA-SOPHOCLEOUS, S.; E. K. CONSTANTINOU; C. N. GIANNIKAS (Eds.). ESP teaching and teacher education: Current theories and practices. Voillans,

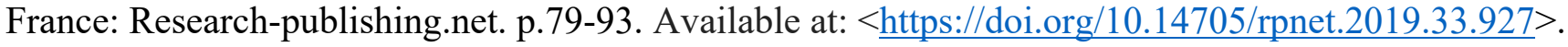
Access: 23 mar. 2020.

CUSHING, S. 1994. Fatal words: Communication clashes and aircraft crashes. Chicago: The University of Chicago Press.

DOUGLAS, D. 2000. Assessing languages for specific purposes. Cambridge: Cambridge University Press. .2001. Language for specific purposes assessment criteria: where do they come from?

Language Testing. 2.18: 171-185. Available at: <https://doi.org/10.1177/026553220101800204>. Access: 24 jun. 2019.

.2004. Assessing the language of international civil aviation: Issues of validity and impact.

Proceedings from the International Professional Communication Conference, IEEE Professional Communication Society. Minneapolis: IEEE. p. 248-252.

2014. Nobody seems to speak English today: Enhancing assessment and training in aviation English. Iranian Journal of Language Teaching Research. 2.2: 1-12. Available at $<$ http://ijltr.urmia.ac.ir/article_20410.html>. Access: 14 jun. 2016.

DOUGLAS, D.; R. K. MYERS. 2000. Assessing the communication skills of veterinary students: Whose criteria? In KUNNAN, A. (Ed.). Fairness in validation in language assessment. Selected papers from the 
19th language testing research colloquium. Studies in Language Testing 9. Cambridge: Cambridge University Press. p. 60-81.

ELDER, C.; T. MCNAMARA. 2016. The hunt for 'indigenous criteria' in assessing communication in the physiotherapy workplace. Language Testing. 33.2: 153-174. Available at $<$ https://doi.org/10.1177/0265532215607398>. Access: 30 nov. 2016.

ELDER, C.; T. MCNAMARA; H. KIM; J. PILL; T. SATO. 2017. Interrogating the construct of communicative competence in language assessment contexts: What the non-language specialist can tell us. Language \& Communication. 57: 14-21. Available at $<$ https://doi.org/10.1016/j.langcom.2016.12.005 $>$. Access: 2 aug. 2018.

ESTIVAL, D. 2018. What should we teach native speakers? In ROBERTS, J.; D. ESTIVAL (Ed.). The Proceedings of the International Civil Aviation English Association (2018) Conference. Daytona Beach/FL, USA. p. 37-46. Available at $<$ https://commons.erau.edu/icaea-workshop/2018/proceedings/1>. Access: 25 apr. 2019.

ESTIVAL, D.; C. FARRIS; B. MOLESWORTH. (Eds.). 2016. Aviation English: A lingua franca for pilots and air traffic controllers. London, UK: Routledge.

EUROCONTROL. 2004. Air-ground communication safety study: an analysis of pilot-controller

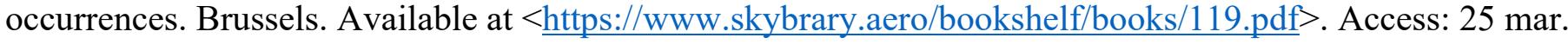
2007.

2006. Air-ground communication safety study: Causes and recommendations.

Available at $<$ https://skybrary.aero/bookshelf/books/162pdf $>$. Access: 25 mar. 2007.

FLIGHT SAFETY FOUNDATION. 2000. Pilot-controller communication. FSF ALAR Briefing Note 2.3 Flight Safety Digest (Aug/Nov). Available at $<$ https://flightsafety.org/wpcontent/uploads/2016/09/alar bn2-3-communication.pdf>. Access: 13 nov. 2006.

FOX, J.; N. ARTEMEVA. 2017. From diagnosis toward academic support: Developing a disciplinary, ESP-based writing task and rubric to identify the needs of entering undergraduate engineering students. ESP Today. 5.2: 148-171. Available at $<$ https://doi.org/10.18485/esptoday.2017.5.2.2>. Access: 13 feb. 2018.

FRIGINAL, E.; E. MATHEWS: J. ROBERTS (Eds.). 2020. English in global aviation: Context, research and perspectives. New York: Bloomsbury Publishing.

FULCHER, G.; F. DAVIDSON. 2007. Language testing and assessment: An advanced resource book. London and New York: Routledge.

GRAYSON, R. L.; C. E. BILLINGS. 1981. Information transfer between air traffic control and aircraft: Communication problems in flight operations. In BILLINGS, C. E.: E. S. CHEANEY (Eds.). Information transfer problems in the aviation system. NASA Technical Paper 1875. p.45-61. Available at $<$ https://ntrs.nasa.gov/archive/nasa/casi.ntrs.nasa.gov/19810022620.pdf > . Access: 13 nov. 2006.

HOFSTEDE, G. 1991. Cultures and organizations: Software of the mind. London: McGraw- Hill. INTERNATIONAL CIVIL AVITION ORGANIZATION. 2010. Manual on the Implementation of ICAO Language Proficiency Requirements: ICAO Doc 9835. (2nd ed.). Montreal, Canada. JACOBY, S.; T. MCNAMARA. 1999. Locating competence. English for Specific Purposes. 18.3: 213-241. Available at <https://doi.org/10.1016/S0889-4906(97)00053-7>. Access: 30 nov. 2016. KIM, H. 2012. Exploring the construct of aviation communication: A critique of the ICAO language proficiency policy. Doctoral Thesis, University of Melbourne, Melbourne, Australia.

. 2013. Exploring the construct of radiotelephony communication: A critique of the ICAO English testing policy from the perspective of Korean aviation experts. Papers in Language Testing and Assessment. 2.2: 103-110. Available at $<$ http://www.altaanz.org/uploads/5/9/0/8/5908292/6 kim.pdf $>$. Access: 10 feb. 2015.

. 2018. What constitutes professional communication in aviation: Is language proficiency enough 
for testing purposes? Language Testing. 35.3: 403-426. Available at <https://doi.org/10.1177/0265532218758127>. Access: 06 jan. 2019.

KIM, H.; ELDER, C. 2009. Understanding aviation English as a lingua franca: perceptions of Korean aviation personnel. Australian Review of Applied Linguistics. 32.3: 23.1-23.17. Available at: $<$ https://benjamins.com/catalog/aral.32.3.03kim>. Access: 10 feb. 2015.

2015. Interrogating the construct of aviation English: Feedback

from test takers in Korea. Language Testing. 32.2: 129-149. Available at $<$ https://doiorg.proxy.library.carleton.ca/10.1177/0265532214544394>. Access: 05 sep. 2016.

KNOCH, U. 2014. Using subject specialists to validate an ESP rating scale: The case of the International Civil Aviation Organization (ICAO) rating scale. English for Specific Purposes. 33: 77-86. Available at $<$ https://doi.org/10.1016/j.esp.2013.08.002>. Access: 05 sep. 2016.

KNOCH, U.; S. MACQUEEN. 2016. Language assessment for the workplace. In TSAGARI, D.: J. BANERJEE (Eds.). Handbook of second language assessment. Berlin: de Gruyter Inc. p. 291-307, e-book. . 2020. Assessing English for professional purposes. Milton: Routledge.

MATHEWS, E. 2011. A review: Language in Human Factors. Available at <https://docs.wixstatic.com/ugd/ff1926 eb5d9d901e984927aa905166c8c245d1.pdf>. Access: 30 apr. 2020. 2018. A linguistic review of aviation accidents. Paper presented at the International Civil Aviation English Association 2018, Daytona Beach, FL, USA. Available at $<$ https://commons.erau.edu/icaea-workshop/2018/wednesday/5>. Access: 06 jan. 2019.

MCMILLAN, D. 1998. “...Say again?...” Miscommunications in air traffic control. Master's Dissertation, Queensland University of Technology, Brisbane, Australia.

MESSICK, S. 1994. The interplay of evidence and consequences in the validation of performance assessments. Educational Researcher. 23.2: 13-23. Available at $<$ https://doi.org/10.3102/0013189X023002013 >. Access: 21 jan. 2016.

MOLESWORTH, B.; D. ESTIVAL. 2015. Miscommunication in general aviation: The influence of external factors on communication errors. Safety Science. 73: 73-79. Available at

$<$ https://doi.org/10.1016/j.ssci.2014.11.004>. Access: 6 sep. 2016.

MONTEIRO, A. L. T. 2012. Radiotelephony communications: Threats in a multicultural context. Aviation in Focus. 3.2: 44-66. Available at $<$ http://revistaseletronicas.pucrs.br/ojs/index.php/aviation/article/view/13085>. Access: 03 mar. 2013. . 2018. Exploring intercultural factors in international pilot-air traffic controller communications: Validating a taxonomy using mixed methods research. In ROBERTS, J.; D. ESTIVAL (Eds.). The Proceedings of the International Civil Aviation English Association (2018) Conference. Daytona Beach/FL, USA. p. 4-36. Available at $<$ https://commons.erau.edu/icaeaworkshop/2018/proceedings/1>. Access: 25 apr. 2019.

2019a. Reconsidering the measurement of proficiency in pilot and air traffic controller radiotelephony communication: From construct definition to task design. Doctoral Thesis, Carleton University, Ottawa, Canada.

2019b. From a language-only approach to a broader view of communicative competence for intercultural communication in aviation. In ROBERTS, J.; D. ESTIVAL (Eds.). The Proceedings of the International Civil Aviation English Association (2019) Conference. Chiba/Tokyo, Japan. p. 78-117. Available at $<$ https://commons.erau.edu/icaea-workshop/2019/proceedings/1>. Access: 06 jan. 2020.

MORRISON, R.; R. H. WRIGHT. 1989. ATC control and communication problems: An overview of recent ASRS data. In JENSEN, R. S. (Ed.). Proceedings of Fifth International Symposium of Psychology. Vol 2. Columbus, OH: OSU. 
MORROW, D. G.; M. RODVOLD. 1998. Communication issues in air traffic control. In MOLENSKY, M.; E. STEIN. (Eds.). Human factors in air traffic control. San Diego: Academic Press. p. 421-456. O'SULLIVAN, B. 2012. Assessment issues in language for specific purposes. The Modern Language Journal. 96. Focus Issue: 71-88. Available at $<$ https://doi.org/10.1111/j.1540-4781.2012.01298.x $>$ Access: 16 feb. 2019.

ORASANU, J. M.; J. DAVISON; U. FISCHER. 1997. What did he say? Culture and language barriers to efficient communication in global aviation. In JENSEN, R. S. (Ed.). Proceedings of the Ninth International Symposium on Aviation Psychology Columbus, OH: OSU. p. 673-678.

PACHECO, A. 2018. Intercultural issues in air-ground communication: A case study - triggers for miscommunication. In ROBERTS, J.; D. ESTIVAL (Eds.). The Proceedings of the International Civil Aviation English Association (2018) Conference. Daytona Beach/FL, USA. p. 47-60. Available at $<$ https://commons.erau.edu/icaea-workshop/2018/proceedings/1>. Access: 25 apr. 2019.

PALTRIDGE, B.; S. STARFIELD (Eds.). 2013. The handbook of English for specific purposes. Malden MA: Wiley-Blackwell.

PILL, J. 2016. Drawing on indigenous criteria for more authentic assessment in a specific purpose language test: Health professionals interacting with patients. Language Testing. 33.2: 175-193. Available at $<$ https://doi.org/10.1177/0265532215607400>. Access: 30 nov. 2016.

PRINZO, O. V.; T. W. BRITTON. 1993. ATC/pilot voice communications: A survey of the literature. Federal Aviation Administration Report DOT/FAA/AM-93. Available at $<$ https://www.faa.gov/data_research/research/med_humanfacs/oamtechreports/1990s/media/am93-20.pdf > Access: 25 mar. 2007.

Ana Lúcia Tavares Monteiro is an ICAEA Board Member and co-leads the ICAEA Research Group. She has been working with the ICAO Language Proficiency Requirements since 2005 at ANAC-Brazil, as a regulator, aviation English test designer, interlocutor, rater and rater trainer. Ana has an MA in Applied Linguistics (UFRJ, Brazil) and a PhD in Applied Linguistics and Discourse Studies (Carleton University, Canada). Her research interests include the impact of cultural factors on pilot-controller communications and the specification of the construct of aviation radiotelephony communication to inform test design.

Neil Bullock is a language specialist focussing on English in professional communication, specifically aviation. Having worked in air traffic control for 20 years, he started teaching business English in 2003 and then developed his language skills in testing, linguistics and teacher training. With an MA in Applied Linguistics, he has developed training courses for Aviation English teachers and has managed the development of language proficiency testing programmes for the Federal Office of Civil Aviation in Switzerland. Neil is ICAEA Vice-President and a committee member of IATEFL Testing, Evaluation and Assessment SIG. 
Appendix. Analysis of a non-routine situation in aeronautical RT communication (Pilot/ATCO)

\begin{tabular}{|c|c|c|c|c|c|}
\hline & & & Response factor & Coded factor & Coded domain \\
\hline 1 & PILOT & $\begin{array}{l}\text { Swiss } 1311 \text { MAYDAY, MAYDAY, MAYDAY bird strike } \\
\text { climbing to } 900 \text { metres height ... proceeding straight } \\
\text { ahead. }\end{array}$ & Situation & Technical knowledge & Ops Knowledge \\
\hline 2 & ATCO & Roger mayday Swiss 1311 would you like RWY 10 L? & Interference & Radio equipment quality & Technical \\
\hline 3 & PILOT & $\begin{array}{l}\text { Via Runway 28R, proceeding straight ahead. Request } \\
\text { radar vectors. }\end{array}$ & $\begin{array}{l}\text { Interference } \\
\text { Improper phraseology }\end{array}$ & $\begin{array}{l}\text { Radio equipment quality } \\
\text { Technical knowledge }\end{array}$ & $\begin{array}{l}\text { Technical } \\
\text { Ops Knowledge }\end{array}$ \\
\hline 4 & ATCO & 110. & Improper phraseology & Technical knowledge & Ops Knowledge \\
\hline 5 & ATCO & Swiss 1311 , identify.... What kind of problem? & $\begin{array}{l}\text { Improper phraseology } \\
\text { Language structure }\end{array}$ & $\begin{array}{l}\text { Technical knowledge } \\
\text { Structure }\end{array}$ & $\begin{array}{l}\text { Ops Knowledge } \\
\text { Linguistic }\end{array}$ \\
\hline 6 & PILOT & $\begin{array}{l}\text { Okay, climbing to } 3100 \text { and request radar vectors, say } \\
\text { again the heading. }\end{array}$ & $\begin{array}{l}\text { Workload } \\
\text { Attention to communication } \\
\text { Improper phraseology }\end{array}$ & $\begin{array}{l}\text { Workload } \\
\text { Monitoring skills } \\
\text { Technical knowledge }\end{array}$ & $\begin{array}{l}\text { Ops Environment } \\
\text { HF - Personal Actions \& } \\
\text { Behaviours } \\
\text { Ops Knowledge }\end{array}$ \\
\hline 7 & ATCO & Swiss 1311 turn left heading 110. & & & \\
\hline 8 & PILOT & Left heading 100, Swiss 1311. & $\begin{array}{l}\text { Not listening well } \\
\text { Attention to communications } \\
\text { (Readback error - pilot) }\end{array}$ & $\begin{array}{l}\text { Listening } \\
\text { Monitoring skills }\end{array}$ & $\begin{array}{l}\text { Linguistic } \\
\text { HF - Personal Actions and } \\
\text { Behaviours }\end{array}$ \\
\hline 9 & ATCO & Swiss 1311 , what is the problem? & $\begin{array}{l}\text { Accent } \\
\text { Attention to communications } \\
\text { (Hear back failure - ATCO) }\end{array}$ & $\begin{array}{l}\text { Accent } \\
\text { Monitoring skills }\end{array}$ & $\begin{array}{l}\text { Linguistic } \\
\text { HF - Personal Actions and } \\
\text { Behaviours }\end{array}$ \\
\hline 10 & PILOT & Say again, Swiss 1311. & & & \\
\hline 11 & ATCO & Swiss 1311 what is the problem ... mayday? & Language structure & Structure & Linguistic \\
\hline 12 & PILOT & Bird strike $\ldots$ bird strike. & $\begin{array}{l}\text { Change in priorities } \\
\text { Workload }\end{array}$ & $\begin{array}{l}\text { Prioritizing } \\
\text { Workload }\end{array}$ & $\begin{array}{l}\text { Ops environment } \\
\text { Ops environment }\end{array}$ \\
\hline 13 & ATCO & Ehh.... Swiss $1311 \ldots$ & $\begin{array}{l}\text { Clarity } \\
\text { Individual not talking properly }\end{array}$ & $\begin{array}{l}\text { Enunciation } \\
\text { Technical knowledge }\end{array}$ & $\begin{array}{l}\text { Linguistic } \\
\text { Ops Knowledge }\end{array}$ \\
\hline 14 & PILOT & Request 10 mile final, Swiss 1311. & & & \\
\hline 15 & ATCO & Swiss 1311, expect. & $\begin{array}{l}\text { Improper phraseology } \\
\text { Language skills (ambiguous - } \\
\text { standby / it should be OK?) }\end{array}$ & $\begin{array}{l}\text { Technical knowledge } \\
\text { Language proficiency }\end{array}$ & $\begin{array}{l}\text { Ops Knowledge } \\
\text { Linguistic }\end{array}$ \\
\hline 16 & PILOT & Roger. & & & \\
\hline 17 & ATCO & Swiss $1311 \ldots$ you....catch... bird? & $\begin{array}{l}\text { Vocabulary } \\
\text { Improper phraseology }\end{array}$ & $\begin{array}{l}\text { Vocabulary } \\
\text { Technical knowledge }\end{array}$ & $\begin{array}{l}\text { Linguistic } \\
\text { Ops Knowledge }\end{array}$ \\
\hline 18 & PILOT & Say again? & & & \\
\hline 19 & ATCO & What is your situation, Swiss $1311 ?$ & Lack of English LP & Language proficiency & Linguistic \\
\hline 20 & PILOT & High vibrations 1 and 2 engines ... 2 engines. & Language structure & Structure & Linguistic \\
\hline 21 & ATCO & Swiss 1311 , eh, because... catch..eh, a bird? & $\begin{array}{l}\text { Vocabulary } \\
\text { situation (ground/flight, normal } \\
\text { ops/emergency... }\end{array}$ & $\begin{array}{l}\text { Vocabulary } \\
\text { Technical knowledge }\end{array}$ & $\begin{array}{l}\text { Linguistic } \\
\text { Ops Knowledge }\end{array}$ \\
\hline 22 & PILOT & Bird strike, affirm, Swiss 1311. & & & \\
\hline
\end{tabular}




\begin{tabular}{|c|c|c|c|c|c|}
\hline 23 & ATCO & $\begin{array}{l}\text { Swiss } 1311 \text {, report when ready turn left for intercept } \\
\text { localizer. }\end{array}$ & & & \\
\hline 24 & PILOT & Will do. & Improper phraseology & Technical knowledge & Ops Knowledge \\
\hline 25 & PILOT & Ok, turning left, Swiss 1311. & & & \\
\hline 26 & ATCO & $\begin{array}{l}\text { Swiss 1311, turn left heading 300, cleared ILS approach } \\
\text { RWY 28R. }\end{array}$ & & & \\
\hline 27 & PILOT & Cleared ILS approach RWY28R and request fire brigade & & & \\
\hline 28 & ATCO & $\begin{array}{l}\text { Swiss } 1311 \text {, we radio for emergency and alert emergency } \\
\text { services. }\end{array}$ & $\begin{array}{l}\text { Language structure } \\
\text { Improper phraseology }\end{array}$ & $\begin{array}{l}\text { Structure } \\
\text { Technical knowledge }\end{array}$ & $\begin{array}{l}\text { Linguistic } \\
\text { Ops Knowledge }\end{array}$ \\
\hline 29 & PILOT & $\begin{array}{l}\text { OK thank you very much. We have two engine problems, } \\
\text { two engine problems. }\end{array}$ & $\begin{array}{l}\text { Language structure } \\
\text { Stress }\end{array}$ & $\begin{array}{l}\text { Structure } \\
\text { Stress \& stress management }\end{array}$ & $\begin{array}{l}\text { Linguistic } \\
\text { HF - Personal influences }\end{array}$ \\
\hline 30 & ATCO & $\begin{array}{l}28 \text { problems? } \\
\text { (Russian) }\end{array}$ & $\begin{array}{l}\text { Situational awareness } \\
\text { Not listening well } \\
\text { Talking in different languages }\end{array}$ & $\begin{array}{l}\text { Mental state } \\
\text { Listening } \\
\text { Code switching }\end{array}$ & $\begin{array}{l}\text { HF - Personal Influences } \\
\text { Linguistic } \\
\text { Sociolinguistic }\end{array}$ \\
\hline 31 & ATCO & $\begin{array}{l}\text { Swiss } 1311 \text { RWY28R visibility } 4300 \text { metres, ceiling } 80 \\
\text { metres }\end{array}$ & Accent & Accent & Linguistic \\
\hline 32 & PILOT & Thank you. & & & \\
\hline 33 & ATCO & Swiss 1311, contact Pulkovo Tower, 118.1. & & & \\
\hline 34 & PILOT & 118.1, bye bye, Swiss 1311 & & & \\
\hline 35 & PILOT & $\begin{array}{l}\text { Ground, hello, Swiss } 1311 \text {, we have stopped at the } \\
\text { intersection. Both engines are shut down. We would like to } \\
\text { have the fire brigade to inspect for any smoke or fire. }\end{array}$ & & & \\
\hline 36 & ATCO & Swiss 1311, Pulkovo Ground, hello. Pass your message. & $\begin{array}{l}\text { Attention to communications } \\
\text { Background noise } \\
\text { Communication deviates from } \\
\text { expectations }\end{array}$ & $\begin{array}{l}\text { Monitoring skills } \\
\text { Noise } \\
\text { Expectations }\end{array}$ & $\begin{array}{l}\text { HF - Personal Actions and } \\
\text { Behaviours } \\
\text { Ops Environment } \\
\text { Ops Environment }\end{array}$ \\
\hline 37 & ATCO & Swiss 1311, Pulkovo Ground. & $\begin{array}{l}\text { Background noise } \\
\text { Situational awareness }\end{array}$ & $\begin{array}{l}\text { Noise } \\
\text { Mental state }\end{array}$ & $\begin{array}{l}\text { Ops Environment } \\
\text { HF - Personal Influences }\end{array}$ \\
\hline 38 & PILOT & Go ahead, Swiss 1311. & Improper phraseology & Technical knowledge & Ops Knowledge \\
\hline 39 & ATCO & Swiss 1311, pass your message please. & Lack of English LP & Language proficiency & $\begin{array}{l}\text { Linguistic ** } \\
\text { (Interaction/Comprehension) }\end{array}$ \\
\hline 40 & PILOT & Please say again? & Mental state & Attention and vigilance & HP - Personal influences \\
\hline 41 & ATCO & Swiss 1311, Pulkovo Ground, wait on Taxiway B4. & Attention to communications & Monitoring skills & $\begin{array}{l}\text { HF - Personal Actions and } \\
\text { Behaviours }\end{array}$ \\
\hline 42 & PILOT & $\begin{array}{l}\text { How can we wait? We have shut down all engines. We } \\
\text { cannot move. We cannot move. We need a tractor. We } \\
\text { need a tractor. }\end{array}$ & $\begin{array}{l}\text { Stress } \\
\text { Communication deviates from the } \\
\text { expectations } \\
\text { Vocabulary }\end{array}$ & $\begin{array}{l}\text { Stress \& stress management } \\
\text { Expectations } \\
\text { Vocabulary }\end{array}$ & $\begin{array}{l}\text { HP - Personal influences } \\
\text { Ops Environment } \\
\text { Linguistic }\end{array}$ \\
\hline 43 & ATCO & Swiss 1311, roger. A car sent for you. & $\begin{array}{l}\text { Background noise } \\
\text { Transmission quality } \\
\text { Vocabulary } \\
\text { Language structure }\end{array}$ & $\begin{array}{l}\text { Noise } \\
\text { Radio equipment quality } \\
\text { Vocabulary } \\
\text { Structure }\end{array}$ & $\begin{array}{l}\text { Ops Environment } \\
\text { Technical } \\
\text { Linguistic } \\
\text { Linguistic }\end{array}$ \\
\hline 44 & ATCO & Swiss 1311 , specify what engine got strike. & Vocabulary & Vocabulary & Linguistic \\
\hline
\end{tabular}




\begin{tabular}{|c|c|c|c|c|c|}
\hline & & & Language structure & Structure & Linguistic \\
\hline 45 & PILOT & $\begin{array}{l}\text { Both engines, engine } 1 \text {, engine } 2 \text {. We had problems. Now } \\
\text { we shut down the engines and the fire brigade should just } \\
\text { look whether there is smoke. }\end{array}$ & Stress & Stress \& stress management & HP - Personal influences \\
\hline 46 & ATCO & Swiss 1311 , do you need disembark passengers? & $\begin{array}{l}\text { Individuals not applying correct } \\
\text { phraseology } \\
\text { Procedural Knowledge } \\
\text { Background noise } \\
\text { Situational awareness } \\
\end{array}$ & $\begin{array}{l}\text { Technical knowledge } \\
\text { Procedures } \\
\text { Noise } \\
\text { Mental state } \\
\end{array}$ & $\begin{array}{l}\text { Ops knowledge } \\
\text { Ops knowledge } \\
\text { Ops Environment } \\
\text { HF - Personal Influences }\end{array}$ \\
\hline 47 & PILOT & No,!! I need a tractor. & $\begin{array}{l}\text { Stress Level } \\
\text { Communication deviates from the } \\
\text { expectations } \\
\text { Vocabulary }\end{array}$ & $\begin{array}{l}\text { Stress \& stress management } \\
\text { Expectations } \\
\text { Vocabulary }\end{array}$ & $\begin{array}{l}\text { HP - Personal influences } \\
\text { Ops Environment } \\
\text { Linguistic }\end{array}$ \\
\hline 48 & ATCO & Swiss 1311, roger, tractor sent for you. & $\begin{array}{l}\text { Background noise } \\
\text { Transmission quality } \\
\text { Vocabulary }\end{array}$ & $\begin{array}{l}\text { Noise } \\
\text { Radio equipment quality } \\
\text { Vocabulary } \\
\end{array}$ & $\begin{array}{l}\text { Ops Environment } \\
\text { Technical } \\
\text { Linguistic }\end{array}$ \\
\hline 49 & PILOT & Did you inform our company? & & & \\
\hline 50 & ATCO & Can you repeat? & Not listening well & Listening & Linguistic \\
\hline 51 & PILOT & Did you inform our company, somebody from the station? & $\begin{array}{l}\text { Vocabulary } \\
\text { Local knowledge (procedures, } \\
\text { geography, etc.) }\end{array}$ & $\begin{array}{l}\text { Vocabulary } \\
\text { Experience }\end{array}$ & $\begin{array}{l}\text { Linguistic } \\
\text { Ops Environment }\end{array}$ \\
\hline 52 & ATCO & $\begin{array}{l}\text { Ah, Swiss } 1311, \text { I don't have any information from your } \\
\text { company. }\end{array}$ & $\begin{array}{l}\text { Language structure } \\
\text { Local knowledge } \\
\text { Procedural knowledge }\end{array}$ & $\begin{array}{l}\text { Structure } \\
\text { Experience } \\
\text { Procedures } \\
\end{array}$ & $\begin{array}{l}\text { Linguistic } \\
\text { Ops Environment } \\
\text { Ops knowledge }\end{array}$ \\
\hline 53 & PILOT & Can you call them? & Attention to communications & Monitoring skills & $\begin{array}{l}\text { HF - Personal Actions and } \\
\text { Behaviours }\end{array}$ \\
\hline 54 & ATCO & $\begin{array}{l}\text { I haven't such, I haven't any information about your } \\
\text { company. I don't know how can I connect with your } \\
\text { representative. }\end{array}$ & $\begin{array}{l}\text { Local knowledge } \\
\text { Procedural knowledge } \\
\text { System knowledge } \\
\end{array}$ & $\begin{array}{l}\text { Experience } \\
\text { Procedures } \\
\text { Procedures } \\
\end{array}$ & $\begin{array}{l}\text { Ops Environment } \\
\text { Ops knowledge } \\
\text { Ops knowledge } \\
\end{array}$ \\
\hline 55 & PILOT & Ok, thank you. & & & \\
\hline
\end{tabular}

